\title{
As razões da crítica
}

\author{
Maria Helena Serôdio
}

Não será por acaso que recentemente em Tessalonica no âmbito de uma reunião do Comité Executivo da Associação Internacional de Críticos de Teatro que coincidia com a atribuição do Prémio Europa 2007 - se voltou a insistir na necessidade de definir, com carácter de urgência e com uma abrangência mundial (tanto quanto a AICT a saberá conceber), um "código deontológico do crítico de teatro". Resultará, entre outras considerações, da consciência do seu valor e, consequentemente, da exigência de responsabilidade que se the coloca no plano cultural e artístico o que, naturalmente, comportará questões não apenas de competência, mas também de rigoroso posicionamento ético.

No que à APCT diz respeito, continuamos a pautarnos por um esforço de séria investigação, reflexão e crítica sobre a realidade do teatro - e não só em Portugal - que esta revista procura dinamizar de forma exigente e plural nas suas diversas secções. Mas não nos eximimos ao compromisso do aplauso que nos merecem alguns dos trabalhos feitos em cena, e que nos leva à atribuição do "Prémio da crítica". Fizemo-lo pelo quarto ano consecutivo, e as razões que motivaram as distinções foram resumidamente enunciadas pelos elementos do júri na cerimónia que teve lugar no belo Jardim de Inverno do São Luiz Teatro Municipal no passado mês de Abril, ocupando aqui - de forma mais desenvolvida nalguns casos - o "Dossiê temático", como, de resto, vem sendo hábito no número da revista que sai em Junho.

Merece ainda destaque nesta edição a entrevista a Mário Barradas "Na primeira pessoa", lembrando a sua diversa, longa e importante carreira de encenador, actor, tradutor e modelador decisivo da descentralização teatral entre nós. Dessa influente tarefa cultural e artística, a que se entregou com entusiasmo e tenacidade, resultou a criação do Centro Cultural de Évora (hoje Cendrev) na sequência da democracia conquistada no 25 de Abril de 1974, e a esse importante pólo de criação (e formação) artística tem, incansavelmente e com uma indiscutível dedicação, devotado o seu tempo, o seu esforço e a sua impenitente paixão.

Também a Companhia de Teatro de Almada é aqui lembrada de forma celebratória - no "Portefólio" - pela extraordinária realização do seu Festival, a festa de teatro por excelência que há 27 anos acende o coração de Almada - e cada vez mais o de Lisboa também - quando chega o mês de Julho. Momentos importantes da sua história são aqui recordados por Rui Pina Coelho e Sebastiana Fadda a partir de uma investigação atenta que passou pela consulta exaustiva de documentação e por uma cuidada selecção de imagens, necessariamente limitada ao número de páginas disponíveis. É no contexto desse festival, desde sempre dirigido competente e entusiasticamente por Joaquim Benite, que a APCT realizará este ano um seminário internacional para críticos. Dedicado às "Ficções dramatúrgicas e cénicas: convergências / confrontações", o seminário contará com a presença de vários críticos estrangeiros, para além de todos os críticos portugueses presentes, e terminará com uma sessão aberta a todos os participantes do Festival - criadores e público - para dar conta das análises e reflexões que a temática mereceu aos participantes e para ouvirmos Aleks Sierz autor do célebre In-Yer-Face Theatre (2001) - falar-nos da dramaturgia inglesa contemporânea que tem vindo a estudar mais atentamente.

Na investigação sobre a história do teatro em Portugal, que aqui estimulamos, salientamos, na secção "Estudos aplicados", o ensaio de Luiz Francisco Rebello sobre a censura e o trabalho de Eduardo Pedrozo sobre a importância seminal do Primeiro Acto - Clube de Teatro em Algés, de que Armando Caldas veio a ser um incansável dinamizador. Para o "Arquivo solto", Ana Campos - a partir da investigação que realizou para a sua excelente tese de mestrado que apresentou à Faculdade de Letras da Universidade de Lisboa - revisitou a dramaturgia dos anos 20 do século passado que a revista De teatro por essa altura promovia.

Na reflexão sobre a realidade do teatro hoje, os "Passos em volta" dão conta de vários espectáculos apresentados em Évora, Lisboa, Caldas da Rainha, Coimbra e Porto respectivamente, do Teatro dos Aloés, Cornucópia, Comuna, Klassikus (e Teatro Nacional D. Maria II), Teatro da Rainha, Escola da Noite, Teatro das Marionetas do Porto e Teatro Nacional São João -, enquanto as "Leituras" nos falam do que se publicou recentemente (em original, reedição, tradução e estudos críticos) a que se acrescentou (como vem sendo regular no número de Junho desta revista) a lista dos livros e revistas publicados em Portugal no ano anterior (aqui, em 2006), num trabalho de recolha criteriosa e atenta de Sebastiana Fadda. Mas no campo da análise da dramaturgia merece ainda destaque o interessante 
ensaio de Vanessa Silva Pereira sobre a escrita de Luísa Costa Gomes (incluída nos "Estudos aplicados").

Sobre o que nos chega de outras paragens, Maria João Almeida fala-nos na secção "Em rede" do que a Internet nos mostra sobre o teatro italiano, e Georges Banu expõe, na rubrica "Estudos aplicados", a sua teoria sobre o actor europeu. Na rubrica "Notícias de fora" falase do Prémio Europa 2007 - atribuído a Robert Lepage e Peter Zadek (ao lado do das "Novas realidades" que recaiu sobre o letão Alvis Hermanis e a sérvia Biljana Srbljanovic -, mas também se alude a Richard Foreman (que estendeu a Portugal o seu projecto de pontes culturais) pela escrita de Kerri Allen, e a Firmin Gémier agora reeditado em França, e sobre quem Tiago Porteiro tece algumas considerações.

A restrição de espaço impede-nos de incluir neste número os dois importantes ensaios - que João Dionísio traduzira e preparara para publicação - dos reputados filólogos Luigi Giuliani e Burghard Dedner que se têm debruçado sobre os dramaturgos Lope de Vega e Georg Büchner, mas a eles daremos o merecido destaque na próxima edição de Dezembro. $E_{1}$ como saberão os que persistem neste tipo de actividade editorial, não são só de espaço as limitações que nos ensombram a tarefa da escrita e publicação. Felizmente, a essas contrariedades vêm respondendo, com um entusiasmo exemplar, os nossos muitos colaboradores, de diferentes idades e formações, mas que de igual modo se entregam à análise e reflexão sobre o teatro que se fez e vai fazendo aquém e além fronteiras. E para estes cúmplices amorosos da crítica de teatro (entendida, como correctamente o faz a APCT, como uma alargada actividade que se exerce de muitas formas e em várias instâncias) vai um agradecimento especial dos que são mais directamente responsáveis por esta publicação. Mas esse agradecimento estende-se ainda a tantos outros que, de diferentes - mas não menos decisivas - formas, nos vêm ajudando nesta tarefa: fotógrafos que, de modo célere e generoso, nos fazem chegar os seus trabalhos, artistas e companhias de teatro que, pacientemente, nos facultam informações, documentos e ilustrações, funcionários extremamente competentes e dedicados que no Museu Nacional do Teatro nos apoiam indefectivelmente, e ainda as instituições que têm aceitado publicitar as suas actividades nesta revista.
Se é o teatro, na sua mais ampla realização, e os seus fazedores os que mais insistentemente concitam a nossa atenção e estudo, também a crítica e os seus cultores ocupam a nossa reflexão. Por isso não podemos deixar de referir dois casos recentes que nos tocaram de muito perto, ainda que de forma diferente: o falecimento de Manuel João Gomes e o expressivo dossiê que o JL - Jornal de letras, artes e ideias (28 de Fevereiro de 2007) dedicou a Carlos Porto, Presidente Honorário da APCT. Nos dois colegas reconhecemos destacados exemplos de dedicação e saber que em muito contribuiram para a documentação e estudo do teatro em Portugal, campo científico que queremos consolidar e alargar, mas que - sabemo-lo de "ciência certa" - se fará na intersecção da arte e do seu estudo quando feitos com seriedade, isenção e competência. Essa é a bitola exigente que escolhemos para nós, para a Associação Portuguesa de Críticos de Teatro, que recentemente renovou os seus órgãos sociais: na Direcção, estão agora Maria Helena Serôdio, Paulo Eduardo Carvalho e João Carneiro; na Mesa da Assembleiageral, Luiz Francisco Rebello e Sebastiana Fadda; e no Conselho Fiscal, contamos com Ana Isabel Vasconcelos, Mónica Guerreiro e Rui Pina Coelho. Esta é a equipa a quem é cometida agora a responsabilidade de dinamizar a actividade da Associação e que se distribui, como é sabido, por múltiplas vertentes. E em todas elas reconhecemos a importância que pode ter a crítica de teatro. Esforçar-nos-emos, com certeza, para estar à altura das suas exigências, tanto na actuação interna, como na relação com as instâncias internacionais, aonde é necessário ir fazendo chegar continuamente, e com rigor, as referências ao espaço cultural e artístico português.

Os valores da generosidade, exigência e seriedade aqui invocados e que têm orientado o nosso labor impõem-se com tanta maior urgência quanto incidentes recentes vieram demonstrar a fragilidade de alguns intervenientes com responsabilidades no nosso sistema teatral, tanto no domínio da criação como no da crítica. Se nos afigura como inaceitável que um qualquer criador possa responder com a ameaça de violência a uma opinião crítica que tome como injusta, igualmente reputamos como lamentável que um crítico se possa servir do espaço público de que dispõe para o exercício da injúria e da difamação pessoal. É com renovada serenidade que continuamos apostados em prosseguir melhores caminhos. 